\title{
Spinel zinc ferrite nanostructured thin-films for enhanced light-harvesting in polycrystalline solar cells
}

\author{
Arun Kumar Shanmugam ${ }^{1}$, Rajasekar Rathanasamy ${ }^{2},{ }^{*}$, Gobinath Velu Kaliyannan ${ }^{1}$, Nithyavathy \\ Nagarajan $^{1}$, Manivasakan Palanisamy ${ }^{3}$ \\ ${ }^{1}$ Department of Mechatronics Engineering, Kongu Engineering College, Perundurai, Tamilnadu, 638060, India \\ ${ }^{2}$ Department of Mechanical Engineering, Kongu Engineering College, Perundurai, Tamilnadu, 638060, India \\ ${ }^{3}$ Department of Chemistry, Bharathiar University Arts and Science College, Modakurichi, Tamil Nadu, 638104, India
}

\begin{abstract}
Spinel zinc ferrite $\left(\mathrm{ZnFe}_{2} \mathrm{O}_{4}\right)$ nanocrystallites are applied as an anti-reflection coating (ARC) for the enhanced light harvesting in polycrystalline silicon solar cells (PCSSC) and its effect were studied. Spinel zinc ferrite nanocrystallites were prepared using precursors of zinc and ferric chloride by co-precipitation method. The morphological, optical, electrical characterizations are comprehensively used to establish the performance of spinel $\mathrm{ZnFe}_{2} \mathrm{O}_{4}$ Nanostructured Thin Films (NTF) covered and uncovered PCSSC. Further, X-ray diffraction and fluorescence analysis have been performed to demonstrate the crystallographic patterns and elemental compositions of $\mathrm{ZnFe}_{2} \mathrm{O}_{4}$ nanocrystallites. The developed spinel $\mathrm{ZnFe}_{2} \mathrm{O}_{4} \mathrm{NTF}$ on PCSSC shows the reduction in reflectivity (20.3\%), improvement in light trapping efficiency (17.5\%) and transmittance of the fabricated spinel $\mathrm{ZnFe} 2 \mathrm{O}_{4} \mathrm{NTF}$ was validated with optical and electrical observations.
\end{abstract}

Keywords: Spinel zinc ferrite nanocrystallites, nanostructured thin films, light-harvesting and anti-reflection coating, polycrystalline silicon solar cells

\section{Introduction}

Global energy consumption is increasing rapidly day by day and the energy produced from fossil fuels may not be sufficient for future requirements [1]. Solar energy is a significant source of renewable energy and an extremely successful renewable resource due to its economic efficiency, enhanced energy performance and ability to be used in a variety of places. Polycrystalline silicon solar cells show less power conversion efficiency (PCE) due to reflection loss and light to heat conversion. One of the main aspects involved in order to achieve high-performance silicon solar cells is to reduce optical losses and increase light transmittance and trapping characteristics. Several techniques were used to increase the PCE and one such effective technique is the use of anti-reflection coating (ARC) $[2,3]$.

Recent studies reveal that magnetic nanoparticles can significantly improve the PCE of solar cells [4]. Magnetic oxide nanoparticles [M(II)

*E-mail: rajasekar.cr@gmail.com
$\mathrm{Fe}(\mathrm{III})_{2} \mathrm{O}_{4}$ where $\mathrm{M}$ represents $\mathrm{Co}, \mathrm{Mn}, \mathrm{Ni}, \mathrm{Zn}$ or $\mathrm{Fe}]$ have attracted considerable interest due to its wide range of applications [5]. Spinel ferrites possessing the cubic structure are described by the formula $\mathrm{AB}_{2} \mathrm{X}_{4}$, where $\mathrm{A}$ and $\mathrm{B}$ indicate tetrahedral and octahedral cation sites, respectively, in an face centred cubic (FCC) anion (oxygen) sublattice. The zinc ferrite $\left(\mathrm{ZnFe}_{2} \mathrm{O} 4\right)$ has a regular spinel structure with $\mathrm{Zn}^{2+}$ ions in the A-site and $\mathrm{Fe}^{3+}$ ions in the B-sites [6] Among the spinel ferrites, $\mathrm{ZnFe}_{2} \mathrm{O}_{4}$ attracts great attention as it is a promising n-type semiconductor photocatalyst with 1.9 eV bandgap [7]. Spinel ferrites are widely used in different applications such as magnetic storage media [7], microwave devices [8], gas sensors [9], wastewater treatment [10], biomedical applications [11, 12], nanoelectronics [13], ferrofluids [14], catalysts [15], batteries [16], but only a few works have been carried out for PCSSC solar cells [17].

Properties of the ferrites are affected by particle size, cation distribution, morphology, synthesis and fabrication methods. $\mathrm{ZnFe}_{2} \mathrm{O}_{4}$ can be synthesized using different methods such as sol-gel 
technique [18-20] co-precipitation [21], hydrothermal [22], solvothermal [23], ball milling [24], and ceramic route [25]. Among them, co-precipitation is a promising technique for ferrite processing due to low production cost, controllable particle size, reactivity, enhanced uniformity and purity [26]. Spin-coating is a commonly used technique for optical coatings to manufacture extremely reproducible film thickness [27]. Single-layer coating on solar cells would not be sufficient to reduce reflection. Therefore, multilayer coating of ARC is often preferred for further reduction of reflection loss [28-30].

This present research work focuses on using the spinel $\mathrm{ZnFe}_{2} \mathrm{O}_{4}$ nanocrystallites as a light harvesting ARC material for enhancing the PCE of polycrystalline silicon solar cells (PCSSC). The $\mathrm{ZnFe}_{2} \mathrm{O}_{4}$ spinel nanocrystallites were synthesized using co-precipitation method, which are deposited on the PCSSC by using spin coating technique. The structural, optical, electrical behaviour of spinel $\mathrm{ZnFe}_{2} \mathrm{O}_{4}$ NTF covered and uncovered PCSSC were investigated under controlled atmospheric condition.

\section{Materials and methods}

\subsection{Materials}

Zinc chloride $\left(\mathrm{ZnCl}_{2}\right)$, ferric chloride $\left(\mathrm{FeCl}_{3} \cdot 6 \mathrm{H}_{2} \mathrm{O}\right)$ and sodium hydroxide $(\mathrm{NaOH})$ with $98 \%$ purity was purchased from Merck Life Science Private Limited (India). Ethanol $\left(\mathrm{C}_{2} \mathrm{H}_{5} \mathrm{OH}\right)$, $99.9 \%$ purity was purchased from Loba Chemical Private Limited (India). PCSSCs with dimensions of $52 \times 38 \mathrm{~mm}$ were purchased from Eco-Worthy (China).

\subsection{Preparation of $\mathrm{ZnFe}_{2} \mathrm{O}_{4}$ spinel nanoparticles}

The $\mathrm{ZnFe}_{2} \mathrm{O}_{4}$ spinel nanoparticles were prepared using $\mathrm{ZnCl}_{2}$ and $\mathrm{FeCl}_{3} \cdot 6 \mathrm{H}_{2} \mathrm{O}$. The dual precursors of $1 \mathrm{~g}$ were dissolved in $100 \mathrm{ml}$ of distilled water and added with $75 \mathrm{ml}$ of $3 \mathrm{M} \mathrm{NaOH}$ solution to act as a co-precipitating agent. After drop by drop addition of $\mathrm{NaOH}$ solution, the obtained solution was magnetically stirred at $750 \mathrm{rpm}$ for two hours, then it was further heated at $75{ }^{\circ} \mathrm{C}$ for one hour. The resultant product was allowed to settle down at room temperature, and its $\mathrm{pH}$ was constantly maintained at 7.5 by subsequent washing with deionised water, causing the removal of chloride $\left(\mathrm{Cl}^{-}\right)$ions. The obtained wet precipitate was placed in a hot air oven at $110^{\circ} \mathrm{C}$ for 12 hours, followed by calcination at $510{ }^{\circ} \mathrm{C}$ for five hours in a muffle furnace. Finally, the obtained calcined $\mathrm{ZnFe}_{2} \mathrm{O}_{4}$ was finely grained for 3 hours using agate mortar and pestle to obtain fine $\mathrm{ZnFe}_{2} \mathrm{O}_{4}$ nanoparticles.

\subsection{Deposition of $\mathrm{ZnFe}_{2} \mathrm{O}_{4}$ spinel ferrites on polycrystalline solar cells}

The solution was prepared by dissolving $0.1 \mathrm{~g}$ of $\mathrm{ZnFe}_{2} \mathrm{O}_{4}$ spinel nanoparticles in $10 \mathrm{ml}$ of ethanol. This solution was stirred by a magnetic stirrer at room temperature for 2 hours to obtain a homogeneous solution. Afterwards, this solution was sonicated for 10 minutes, and again the solution was stirred for 15 minutes at room temperature. Prior to deposition, the PCSSCs were cleaned with ethanol. The spinel $\mathrm{ZnFe}_{2} \mathrm{O}_{4}$ nanostructures were deposited on PCSSC by spin coating technique with a constant speed of $3000 \mathrm{rpm}$ for a time period of $30 \mathrm{sec}$. The spinel $\mathrm{ZnFe}_{2} \mathrm{O}_{4}$ nanostructures were deposited as layer by layer (LBL) assembly, 1 to 4 layers (L1, L2, L3, and L4) were deposited. After each layer of deposition, PCSSC was dried at $80{ }^{\circ} \mathrm{C}$ for $20 \mathrm{~min}$ in a hot air oven. The pictorial representation for the synthesis of spinel $\mathrm{ZnFe}_{2} \mathrm{O}_{4}$ nanoparticles and deposition of spinel $\mathrm{ZnFe}_{2} \mathrm{O}_{4}$ nanostructures was shown in Fig. 1 .

\subsection{Characterization techniques}

The crystallographic features, crystalline size and phase of the synthesized samples were found using X-ray diffraction (XRD) on Smartlab SE, Rigaku, Canada. The $\mathrm{CuK} \alpha$ radiation with a wavelength of: $1.541 \AA$ and scanning rate of $0.5^{\circ} \mathrm{min}^{-1}$ by varying step size of $0.02^{\circ}$ were used for measurements. XRD measurements were recorded in the range of $2 \theta=20-80^{\circ}$. The chemical composition of the synthesized sample calcinated at $510{ }^{\circ} \mathrm{C}$ was identified using energy dispersive X-Ray 


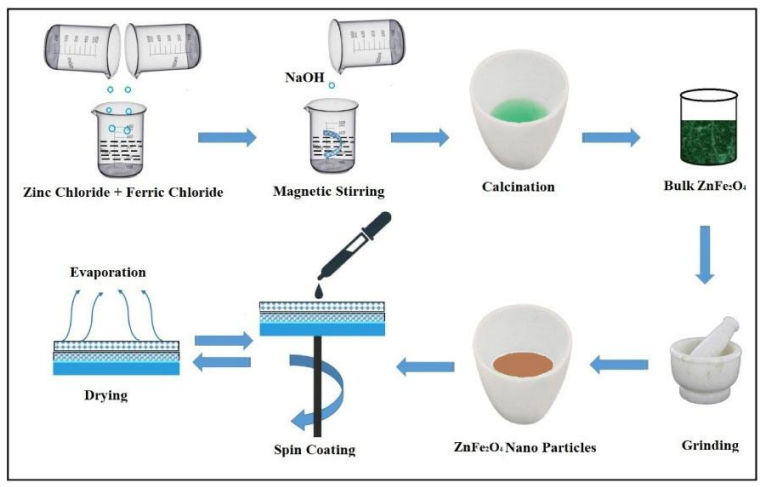

Fig. 1. Pictorial representation for the synthesis of spinel $\mathrm{ZnFe}_{2} \mathrm{O}_{4}$ nanoparticles and deposition of spinel $\mathrm{ZnFe}_{2} \mathrm{O}_{4}$ nanostructures

Fluorescence (XRF), Bruker, USA. The elemental composition of spinel $\mathrm{ZnFe}_{2} \mathrm{O}_{4}$ nanocrystallites coated PCSSC were analysed by Energy Dispersed $\mathrm{X}$-ray Analysis (EDAX). The thickness of spinel $\mathrm{ZnFe}_{2} \mathrm{O}_{4}$ nanocrystalline films coated PCSSC were measured using Atomic Force Microscopy (AFM, NX 10, PARK systems). The transmittance and reflectivity of spinel $\mathrm{ZnFe}_{2} \mathrm{O}_{4}$ nanocrystallites coated samples were examined by UV Spectrophotometer, Shimadzu PC 1650 model. The surface morphology of the spinel $\mathrm{ZnFe}_{2} \mathrm{O}_{4}$ nanocrystallites coated PCSSC was characterized by Field Emission Scanning Electron Microscopy (FE-SEM, MIRA 3, TESCAN, USA). The I-V characteristics of spinel $\mathrm{ZnFe}_{2} \mathrm{O}_{4}$ nanocrystallites coated and uncoated PCSSC were determined using Keithley I-V meter (Model - 4240). The resistivity of pure and spinel $\mathrm{ZnFe}_{2} \mathrm{O}_{4}$ nanocrystallites coated PCSSC was determined using the Four Probe technique.

\section{Results and discussion}

The XRD pattern of the as synthesized $\mathrm{ZnFe}_{2} \mathrm{O}_{4}$ sample calcinated at $510{ }^{\circ} \mathrm{C}$ is shown in Fig. 2. From the XRD pattern, it is observed that the obtained diffraction peaks can be clearly indexed with the spinel face centred cubic symmetry and the crystallographic peaks are well matched to the standard powder diffraction data, JCPDS Card No. 82-1042. The obtained Miller indices (220), (311), (400), (422), (511), (440) are substantially indexed with the spinel $\mathrm{ZnFe}_{2} \mathrm{O}_{4}$ structure. The most significant peak at the plane (311) was used to measure the approximate size of crystallite using Scherrer formula. The Miller indices and position of diffraction peaks of as synthesized spinel $\mathrm{ZnFe}_{2} \mathrm{O}_{4}$ are in accordance with the earlier report [31].

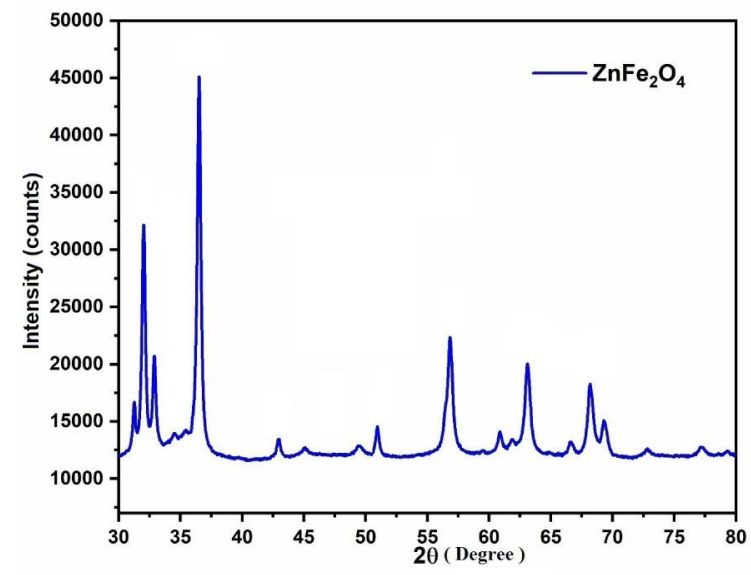

Fig. 2. XRD pattern of as synthesized spinel $\mathrm{ZnFe}_{2} \mathrm{O}_{4}$ nanocrystallites.

The crystallite size D was calculated using the Debye-Scherrer equation as follows:

$$
D=\frac{0.9 \lambda}{\beta \cos \theta}
$$

where, $\lambda$ is the wavelength of $\mathrm{X}$-ray, $\beta$ is the Full Width at Half Maximum (FWHM) value of diffraction peaks and $\theta$ is the Bragg diffraction angle. It can be seen from Table 1 that all the diffraction peaks typically imitates the presence of nanocrystallites with size range of 40 to $104 \mathrm{~nm}$. The efficiency of the PCSSC were increased for the nanocrystallites having higher size. The increase in output was followed by a major shift in short circuit current density (Jsc), with the difference in size.

Table 2 displays the XRF analysis of as synthesized spinel $\mathrm{ZnFe}_{2} \mathrm{O}_{4}$ nanocrystallites and shows their chemical compositions. As seen in Table 2, the chemical composition in the sample is well agreed with the elemental compositions of spinel $\mathrm{ZnFe}_{2} \mathrm{O}_{4}$. The atomic and molecular percentage of zinc and iron oxide confirms the formation of spinel zinc ferrite with chemical composition of 
Table 1. Average crystallite sizes of $\mathrm{ZnFe}_{2} \mathrm{O}_{4}$ sample determined from various diffraction lines

\begin{tabular}{ccc}
\hline 2 Theta & FWHM & $\begin{array}{c}\text { Crystallite Size } \\
\text { D (nm) }\end{array}$ \\
\hline \hline 32.8560 & 0.1407 & 58.86575 \\
34.6856 & 0.2047 & 40.65779 \\
36.4940 & 0.1919 & 43.58997 \\
43.0009 & 0.1791 & 47.67414 \\
47.7918 & 0.1023 & 84.93736 \\
56.4434 & 0.1279 & 70.49320 \\
63.0784 & 0.0895 & 104.1472 \\
68.3362 & 0.1023 & 93.85715 \\
\hline
\end{tabular}

$\mathrm{Zn}_{1} \mathrm{Fe}_{2} \mathrm{O}_{4}$. Further, it can be seen from XRF analysis that the obtained spinel $\mathrm{ZnFe}_{2} \mathrm{O}_{4}$ nanocrystallites has $99.5 \%$ purity with very low quantity of other metal oxides including $\mathrm{MnO}, \mathrm{CaO}, \mathrm{CuO}$, $\mathrm{NiO}, \mathrm{Sc}_{2} \mathrm{O}_{3}$ and $\mathrm{Cr}_{2} \mathrm{O}_{3}$.

FTIR spectra is used to analyse the presence of metal oxides lattice vibrations in high energy fingerprint region as well as the organic functional bonding vibrations at low energy region. FTIR spectra as a function of transmittance (\%) versus wavenumber $\left(v^{-}\right)$is displayed in Fig. 3. The transmittance bands at around 559 and $696 \mathrm{~cm}^{-1}$ indicates the lattice vibrations of the metal oxide ion composed of tetrahedrally coordinated $\mathrm{Fe}$ $\mathrm{O}$ bond of the regular spinel ferrites whereas the band at around $400 \mathrm{~cm}^{-1}$ is associated with the octahedrally coordinated Fe-O bond lattice vibrations [32].

The characteristic FTIR band at $3385 \mathrm{~cm}^{-1}$ indicates the presence of water $(\mathrm{O}-\mathrm{H}$ stretching frequency) molecules adsorbed on the surface of $\mathrm{ZnFe}_{2} \mathrm{O}_{4}$ nanocrystallites. The band at $2917 \mathrm{~cm}^{-1}$ is due to the stretching vibration of $\mathrm{C}-\mathrm{H}$ bond and the characteristic bands present at $1631 \mathrm{~cm}^{-1}$ is due to the stretching frequency of $\mathrm{C}=\mathrm{C}$ bonds. It can be revealed from FTIR analysis that the synthesized spinel $\mathrm{ZnFe}_{2} \mathrm{O}_{4}$ nanocrystallites has adsorbed carbon residue after calcinations and it is due to the usage of precursor ethanolic medium.

The surface topography, morphology and coating thickness of multilayer spinel $\mathrm{ZnFe}_{2} \mathrm{O}_{4}$ nanocrystallites coated PCSSCs were demonstrated using three dimensional (3D) AFM topog-

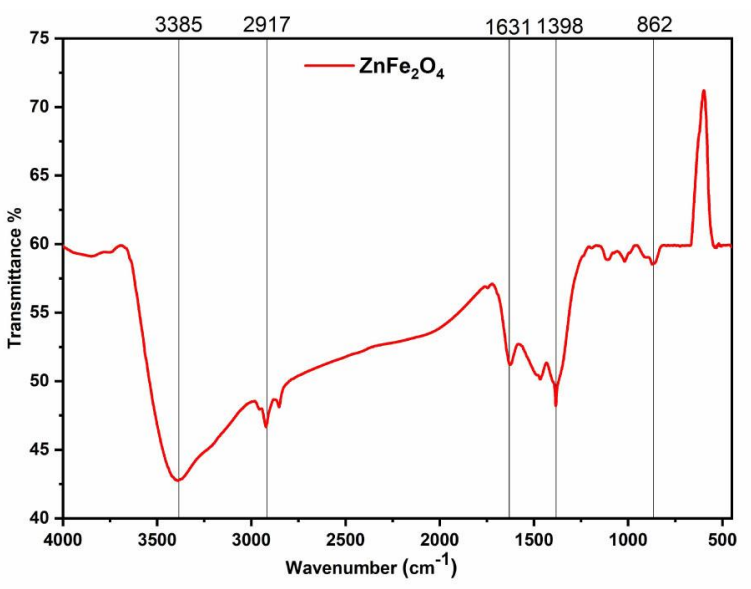

Fig. 3. FTIR spectra of as synthesized spinel $\mathrm{ZnFe}_{2} \mathrm{O}_{4}$ nanocrystallites.

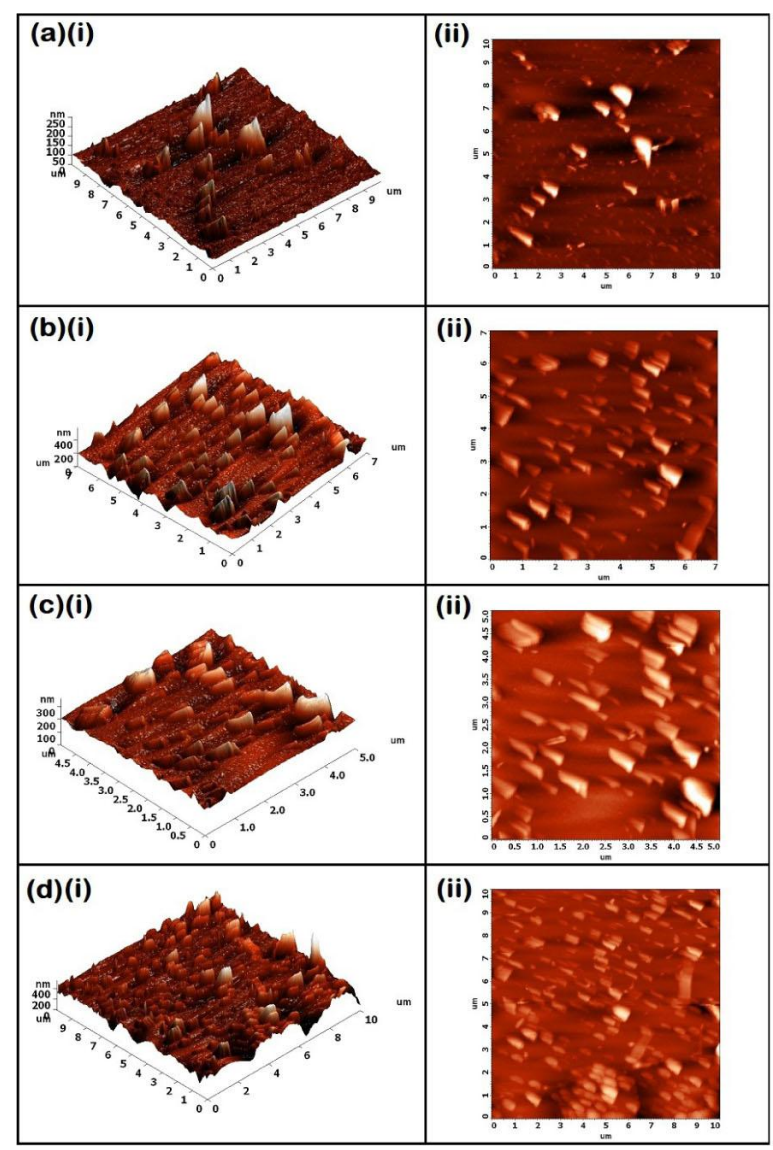

Fig. 4. AFM images of spinel $\mathrm{ZnFe}_{2} \mathrm{O}_{4}$ nanocrystallites coated PSSCs: a) single layer coating, b) double layers coating, c) triple layers coating and d) quarter layers coating 
Table 2. XRF analysis of as synthesized spinel $\mathrm{ZnFe}_{2} \mathrm{O}_{4}$ nanocrystallites

\begin{tabular}{lllllllll}
\hline Elements & $\mathrm{ZnO}$ & $\mathrm{Fe}_{2} \mathrm{O}_{3}$ & $\mathrm{MnO}$ & $\mathrm{CaO}$ & $\mathrm{CuO}$ & $\mathrm{NiO}$ & $\mathrm{Sc}_{2} \mathrm{O}_{3}$ & $\mathrm{Cr}_{2} \mathrm{O}_{3}$ \\
\hline \hline Chemical Composition (\%) & 33.377 & 66.157 & 0.280 & 0.072 & 0.071 & 0.025 & 0.014 & 0.002 \\
\hline
\end{tabular}

raphy images. Fig. 4 exhibits the 3D AFM images of the layer by layer assembly of spinel $\mathrm{ZnFe}_{2} \mathrm{O}_{4}$ nanocrystallites modified PCSSC: a) single layer coating, b) double layers coating, c) triple layers coating and d) quarter layers coating. It can be seen from AFM analysis that the surface thickness of the L1, L2, L3 and L4 are found to be $103 \mathrm{~nm}, 205 \mathrm{~nm}, 260 \mathrm{~nm}$ and $431 \mathrm{~nm}$ respectively. The thickness and average particle size of the spinel $\mathrm{ZnFe}_{2} \mathrm{O}_{4}$ nanocrystallites assembly is increased due to the formation of multiple layer coating as well as the presence of $\mathrm{Zn}^{2+}$ ions in ferrite $\left(\mathrm{Fe}_{2} \mathrm{O}_{3}\right)$ matrix influences the growth of particle size during the curing process [3]. AFM observation clearly indicates the formation of thin film growth processes with more aggregation of hard segments. Nano-micro phase separation can be observed in $\mathrm{ZnFe}_{2} \mathrm{O}_{4}$ nanocrystallites coated PCSSC with higher contents of $\mathrm{ZnFe}_{2} \mathrm{O}_{4}$ groups.

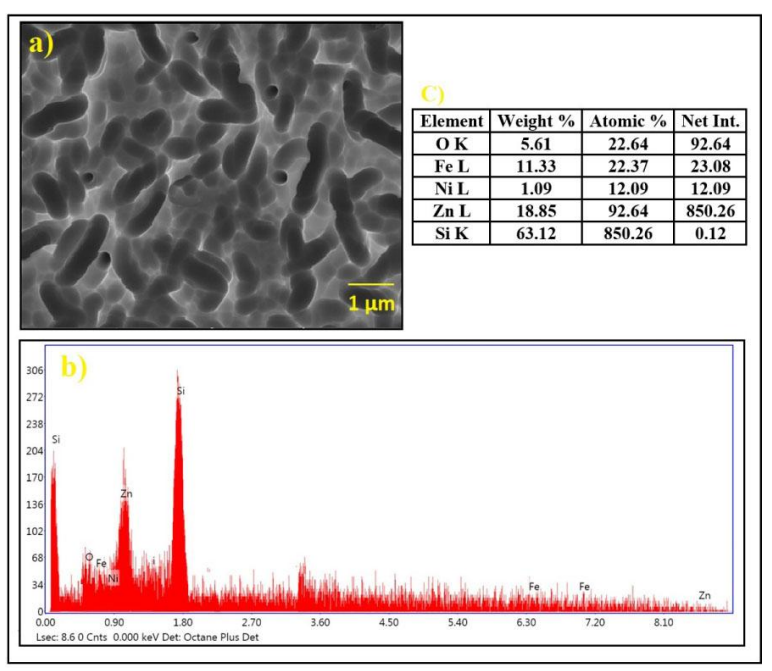

Fig. 5. (a) FE-SEM, (b) EDAX spectra and (c) percentage of the elemental composition of $\mathrm{ZnFe}_{2} \mathrm{O}_{4}$ three layer (L3) coated PSSC.

The morphology and elemental composition of spinel $\mathrm{ZnFe}_{2} \mathrm{O}_{4}$ nanocrystallites coated (L3 Layer) PCSSC were measured using FE-SEM coupled with EDAX. The FE-SEM and EDAX spectra of the three layer (L3) coated PCSSC were displayed in Fig. 5(a) and Fig. 5(b). It can been observed from FE-SEM analysis that the spinel $\mathrm{ZnFe}_{2} \mathrm{O}_{4}$ nanocrystallites are uniformly assembled as cylindrical structure on PCSSC. The elemental composition of the layer three (L3) coated PCSSC was measured using EDAX at room temperature. Fig. 5(c) presents the elemental composition of spinel $\mathrm{ZnFe}_{2} \mathrm{O}_{4}$ nanocrystallites coated (L3 layer) PCSSC and confirms the presence of elemental Zn, $\mathrm{Fe}$ and $\mathrm{O}$ with trace amount of $\mathrm{Ni}$. The percentage values obtained for $\mathrm{Zn}, \mathrm{Fe}, \mathrm{Si}, \mathrm{Ni}$ and $\mathrm{O}$ elements are shown in Fig. 5(c). It is noted that the corresponding atomic mass ratio of the spinel ferrites are well aligned with the prepared stoichiometric ratio. The EDAX spectra and elemental composition (Fig. 5b \& c) supports the presence of $\mathrm{ZnFe}_{2} \mathrm{O}_{4}$ nanocrystallites in surface coating on PCSSC.

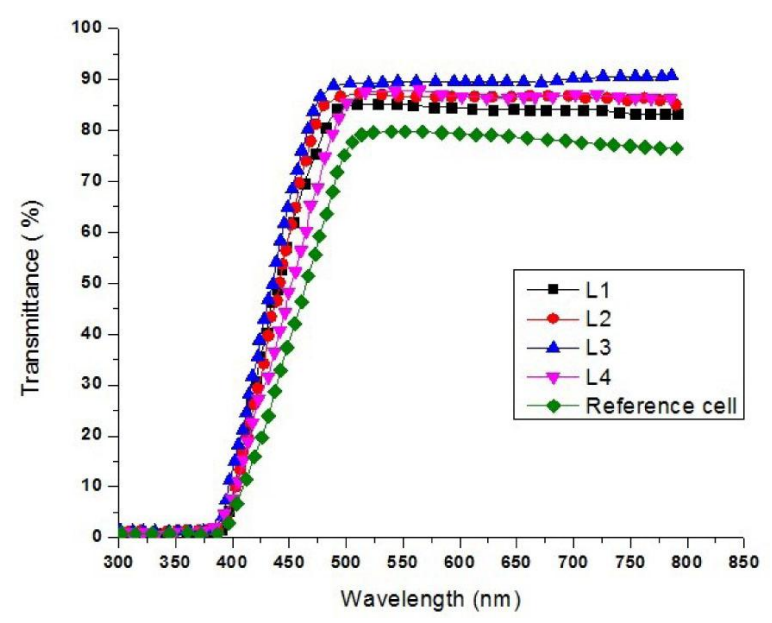

Fig. 6. UV transmittance spectra of spinel $\mathrm{ZnFe}_{2} \mathrm{O}_{4}$ nanocrystallites coated and uncoated solar cells

Fig. 6 and 7 depicts the transmittance and reflectance of $\mathrm{ZnFe}_{2} \mathrm{O}_{4}$ samples with various film thicknesses. All the spinel $\mathrm{ZnFe}_{2} \mathrm{O}_{4}$ nanocrystallites coated samples rendered better transmittance, higher than $85 \%$. The transparency gradually in- 
creases and reflection decreases from L1 to L3 deposition while reverse effect on reflection was observed in L4 layer deposition due to the aggregation of crystallites.

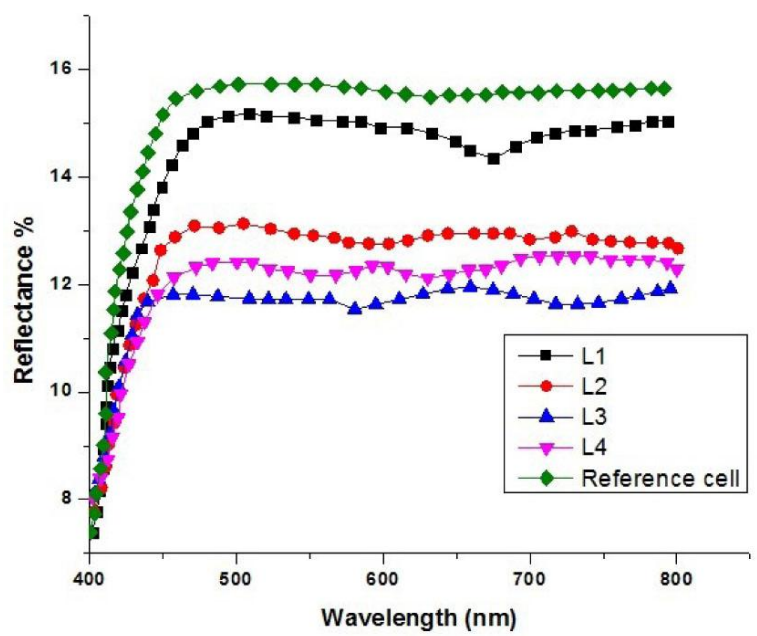

Fig. 7. Reflectance of spinel $\mathrm{ZnFe}_{2} \mathrm{O}_{4}$ nanocrystallites coated and uncoated solar cells.

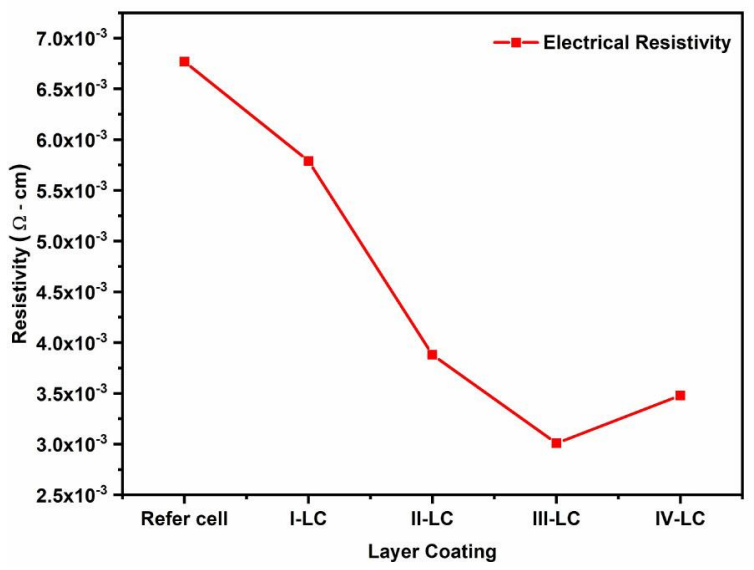

Fig. 8. Electrical resistivity of spinel $\mathrm{ZnFe}_{2} \mathrm{O}_{4}$ nanocrystallites coated PSSCs.

This also demonstrates the importance of thickness on reflection characteristics of spinel $\mathrm{ZnFe}_{2} \mathrm{O}_{4}$ nanocrystallites coating. It can be confirmed from Fig. 6 and 7 that the layer thickness influences the optical transparency as well as anti-reflection capacity of spinel $\mathrm{ZnFe}_{2} \mathrm{O}_{4}$ nanocrystallites functionalized silicon solar cells. It can be noted that
L4 not only lost its transparency, but it also increased its reflection properties and reduced the anti-reflection behaviour due to the aggregation of spinel $\mathrm{ZnFe}_{2} \mathrm{O}_{4}$ nanocrystallites in coating microstructure.

Fig. 8 shows the resistivity of the spinel $\mathrm{ZnFe}_{2} \mathrm{O}_{4}$ nanocrystallites, which is measured by using Four Probe technique. The L3 layer coating on the PCSSC shows minimum resistivity of $3.0 \times 10^{-3} \Omega \mathrm{cm}$ compared to the reference (uncoated) PCSSC resistivity of $6.8 \times 10^{-3} \Omega \mathrm{cm}$ (Fig. 8). Further, the slight increase in the electrical resistivity of the L4 layer may be due to the change in crystalline size without any change in crystal orientation based on the thickness effect [3, 4].

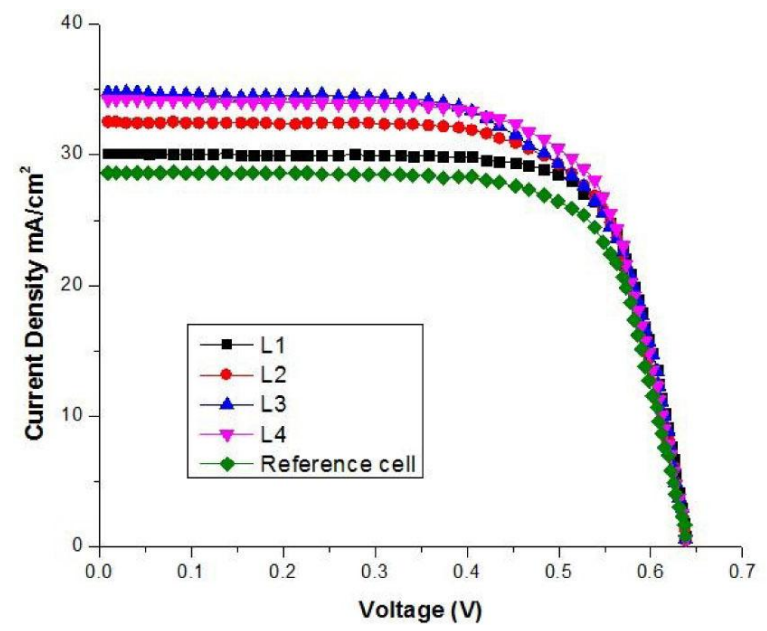

Fig. 9. I-V characteristics of spinel $\mathrm{ZnFe}_{2} \mathrm{O}_{4}$ nanocrystallites coated and uncoated PSSCs.

Fig. 9 presents the I-V characteristics of the spinel $\mathrm{ZnFe}_{2} \mathrm{O}_{4}$ nanocrystallites coated and uncoated PCSSC with the dimensions of $52 \mathrm{~mm} \times$ $32 \mathrm{~mm}$. The I-V characteristics were performed using a solar simulator under a closed-loop light stabilization system with the simulated 1.5 AM global spectrum. It clearly shows that the increased layers of spinel $\mathrm{ZnFe}_{2} \mathrm{O}_{4}$ nanocrystallites coating increases the open circuit voltage (Voc), short circuit current (Isc), fill factor and the efficiency $\eta$ (\%), as shown in the Table 3. Three layers of spinel $\mathrm{ZnFe}_{2} \mathrm{O}_{4}$ nanocrystallites deposited PCSSC demonstrates relatively higher Isc and Voc with en- 
Table 3. PCE of spinel $\mathrm{ZnFe}_{2} \mathrm{O}_{4}$ nanocrystallites coated and uncoated PSSCs.

\begin{tabular}{lllll}
\hline Solar cell & $\begin{array}{l}\mathbf{J}_{\mathrm{sc}} \\
\left(\mathbf{m A} / \mathbf{c m}^{2}\right)\end{array}$ & $\begin{array}{l}V_{\mathrm{oc}} \\
(\mathbf{V})\end{array}$ & $\begin{array}{l}\text { Fill factor } \\
(\boldsymbol{\%})\end{array}$ & Efficiency $\eta(\boldsymbol{\%})$ \\
\hline \hline Ref. cell & 32.1 & 0.625 & 76 & 15.24 \\
L1 & 33.6 & 0.636 & 76.4 & 16.37 \\
L2 & 37.71 & 0.64177 .1 & 18.63 \\
L3 & 39.30 & 0.652 & 78.2 & 20.03 \\
L4 & 38.5 & 0.65177 .5 & 19.39 \\
\hline
\end{tabular}

hanced power conversion efficiency (PCE) than the reference (uncoated) and other coated PCSSC.

\section{Conclusion}

Nanocrystalline spinel $\mathrm{ZnFe}_{2} \mathrm{O}_{4}$ was prepared from precursors $\left(\mathrm{ZnCl}_{2}\right.$ and $\left.\mathrm{FeCl}_{3} \cdot 6 \mathrm{H}_{2} \mathrm{O}\right)$ through simple co-precipitation method. The prepared spinel $\mathrm{ZnFe}_{2} \mathrm{O}_{4}$ nanocrystallites were comprehensively characterized by XRD, XRF and FTIR spectroscopy. Spin coating technique was used to fabricate multilayer spinel $\mathrm{ZnFe}_{2} \mathrm{O}_{4}$ nanocrystallites coatings on PCSSC. The microstructure, morphology, composition of deposited thin films was characterized by AFM, FESEM and EDAX analysis. The transmittance, reflectance, electrical, light harvesting and solar energy conversion properties of developed thin film coatings on PCSSC was demonstrated using UVvisible spectroscopy, four probe technique and I$\mathrm{V}$ characterization respectively. The present research outputs confirm that the developed spinel $\mathrm{ZZnFe}_{2} \mathrm{O}_{4}$ nanocrystallites thin films accommodate the transmittance of $90.1 \%$ and the reduction in reflectivity of $20.3 \%$ with improved light trapping and harvesting efficiency of $17.5 \%$. Remarkably, 20\% enhanced PCE of PCSSC has been achieved by deposition of L3 layer coated $(260 \mathrm{~nm}$ thickness) spinel $\mathrm{ZnFe}_{2} \mathrm{O}_{4}$ nanocrystallites thin films on PCSSC. Hence, it is evident that the spinel $\mathrm{ZnFe}_{2} \mathrm{O}_{4}$ nanocrystallites act as a suitable light harvesting and anti-reflection material for PCSSC.

\section{References}

[1] Devabhaktuni V, Alam M, Depuru SS, Green RC 2nd, Nims D, Near C. Solar energy: trends and enabling tech- nologies. Renew Sustain Energy Rev. 2013;19:555-64. https://doi.org/10.1016/j.rser.2012.11.024

[2] Shi E, Li H, Yang L, Zhang L, Li Z, Li P, et al. Colloidal antireflection coating improves graphene-silicon solar cells. Nano Lett. 2013 Apr;13(4):1776-81. https:// doi .org/10.1021/n1400353fPMID : 23517083

[3] Saylan S, Milakovich T, Hadi SA, Nayfeh A, Fitzgerald EA, Dahlem MS. Multilayer antireflection coating design for GaAs0.69P0.31/Si dual-junction solar cells. Sol Energy. 2015;122:76-86. https://doi.org/10. 1016/j.solener.2015.07.049

[4] Zhang W, Xu Y, Wang H, Xu C, Yang S. Fe3O4 nanoparticles induced magnetic field effect on efficiency enhancement of P3HT:PCBM bulk heterojunction polymer solar cells. Sol Energy Mater Sol Cells. 2011;95(10):2880-5. https://doi .org/10.1016/j . solmat.2011.06.005

[5] Kmita A, Pribulova A, Holtzer M, Futas P, Roczniak A. Use of Specific Properties of Zinc Ferrite in Innovative Technologies. Arch Metall Mater. 2016;61(4):2141-6. https://doi.org/10.1515/amm-2016-0289

[6] Atif M, Hasanain S, Nadeem M. Magnetization of sol-gel prepared zinc ferrite nanoparticles: effects of inversion and particle size. Solid State Commun. 2006;138(8):416-21. https ://doi .org/10.1016/j . ssc. 2006.03.023

[7] Kant Sharma R, Ghose R. Synthesis and characterization of nanocrystalline zinc ferrite spinel powders by homogeneous precipitation method. Ceram Int. 2015;41:14684. https://doi.org/10.1016/j . ceramint.2015.07.191

[8] Huang $\mathrm{X}$, Zhang J, Rao W, Sang T, Song B, Wong C. Tunable electromagnetic properties and enhanced microwave absorption ability of flaky graphite/cobalt zinc ferrite composites. J Alloys Compd. 2016;662:409-14. https : //doi.org/10.1016/j.jallcom.2015.12.076

[9] Zhu H, Gu X, Zuo D, Wang Z, Wang N, Yao K. Microemulsion-based synthesis of porous zinc ferrite nanorods and its application in a roomtemperature ethanol sensor. Nanotechnology. 2008 Oct;19(40):405503. https://doi.org/10.1088/ 0957-4484/19/40/405503 PMID:21832619

[10] Mandal S, Natarajan S, Tamilselvi A, Mayadevi S. Pho- 
tocatalytic and antimicrobial activities of zinc ferrite nanoparticles synthesized through soft chemical route: A magnetically recyclable catalyst for water/wastewater treatment. J Environ Chem Eng. 2016;4(3):2706-12. https://doi.org/10.1016/j.jece.2016.05.020

[11] Chaudhary R, Roy K, Kanwar RK, Walder K, Kanwar JR. Engineered atherosclerosis-specific zinc ferrite nanocomplex-based MRI contrast agents. $J$ Nanobiotechnology. 2016 Jan;14(1):6. https://doi. org/10.1186/s12951-016-0157-1 PMID:26775253

[12] Alhadlaq HA, Akhtar MJ, Ahamed M. Zinc ferrite nanoparticle-induced cytotoxicity and oxidative stress in different human cells. Cell Biosci. 2015 Sep;5(1):55. https://doi.org/10.1186/s13578-015-0046-6 PMID:26388990

[13] Prasad BD, Nagabhushana H, Thyagarajan K, Sharma $\mathrm{S}$, Shivakumara $\mathrm{C}$, Gopal $\mathrm{N}$, et al. Incorporation of $\mathrm{Cr} 3+$ ions in tuning the magnetic and transport properties of nano zinc ferrite. $J \mathrm{Al}$ loys Compd. 2016;657:95-108. https://doi.org/ 10.1016/j.jallcom.2015.09.270

[14] Shahsavar A, Ansarian R, Bahiraei M. Effect of line dipole magnetic field on entropy generation of $\mathrm{Mn}-\mathrm{Zn}$ ferrite ferrofluid flowing through a minichannel using two-phase mixture model. Powder Technol. 2018;340:370-9. https ://doi .org/10.1016/j . powtec.2018.09.052

[15] Liu SQ, Zhu XL, Zhou Y, Meng ZD, Chen ZG, Liu $\mathrm{CB}$, et al. Smart photocatalytic removal of ammonia through molecular recognition of zinc ferrite/reduced graphene oxide hybrid catalyst under visible-light irradiation. Catal Sci Technol. 2017;7(15):3210-9. https : //doi.org/10.1039/C7CY00797C

[16] Sun X, Zhang H, Zhou L, Huang X, Yu C. Polypyrrole-Coated Zinc Ferrite Hollow Spheres with Improved Cycling Stability for Lithium-Ion Batteries. Small. 2016 Jul;12(27):3732-7. https://doi.org/ 10.1002/smll. 201601143 PMID:27259158

[17] Habibi MH, Habibi AH, Zendehdel M, Habibi M. Dyesensitized solar cell characteristics of nanocomposite zinc ferrite working electrode: effect of composite precursors and titania as a blocking layer on photovoltaic performance. Spectrochim Acta A Mol Biomol Spectrosc. 2013 Jun;110:226-32. https://doi.org/10. 1016/j .saa. 2013.03.051 PMID:23571086

[18] Chatterjee A, Das D, Pradhan S, Chakravorty D. Synthesis of nanocrystalline nickel-zinc ferrite by the sol-gel method. J Magn Magn Mater. 1993;127(1-2):214-8. https://doi.org/10.1016/0304-8853(93) 90217-P

[19] Kaliyannan GV, Palanisamy SV, Palanisamy M, Subramanian M, Paramasivam P, Rathanasamy R. Development of sol-gel derived gahnite anti-reflection coating for augmenting the power conversion efficiency of polycrystalline silicon solar cells. Mater Sci Pol. 2019;37(3):465-72. https://doi.org/10. 2478/msp-2019-0066
[20] Gul I, Ahmed W, Maqsood A. Electrical and magnetic characterization of nanocrystalline $\mathrm{Ni}-\mathrm{Zn}$ ferrite synthesis by co-precipitation route. J Magn Magn Mater. 2008;320(3-4):270-5. https://doi.org/10. $1016 / j \cdot j m m m .2007 .05 .032$

[21] Gul I, Ahmed W, Maqsood A. Electrical and magnetic characterization of nanocrystalline $\mathrm{Ni}-\mathrm{Zn}$ ferrite synthesis by co-precipitation route. J Magn Magn Mater. 2008;320(3-4):270-5. https://doi.org/10. $1016 / j \cdot j m m m .2007 .05 .032$

[22] Komarneni S, D’Arrigo MC, Leonelli C, Pellacani GC, Katsuki H. Microwave-hydrothermal synthesis of nanophase ferrites. J Magn Magn Mater. 1998;81:3041.

[23] Yan W, Jiang W, Zhang Q, Li Y, Wang H. Structure and magnetic properties of nickel-zinc ferrite microspheres synthesized by solvothermal method Mater Sci Eng B. 2010;171(1-3):144-8. https://doi.org/10. 1016/j.mseb.2010.03.088

[24] Kim W, Saito F. Mechanochemical synthesis of zinc ferrite from zinc oxide and $\alpha-\mathrm{Fe} 2 \mathrm{O} 3$. Powder Technol. 2001;114(1-3):12-6. https://doi.org/10. 1016/S0032-5910(00)00256-4

[25] Niyaifar M. Effect of Preparation on Structure and Magnetic Properties of $\mathrm{ZnFe}_{2} \mathrm{O}_{4} . \quad J$ Magn. 2014;19(2):101-5. https://doi.org/10.4283/ JMAG . 2014 .19.2 . 101

[26] Venkataraju C, Sathishkumar G, Sivakumar K. Effect of cation distribution on the structural and magnetic properties of nickel substituted nanosized $\mathrm{Mn}-\mathrm{Zn}$ ferrites prepared by co-precipitation method. J Magn Magn Mater. 2010;322(2):230-3. https://doi.org/ 10.1016/j.jmmm.2009.08.043

[27] Velu Kaliyannan G, Palanisamy SV, Palanisamy M, Chinnasamy M, Somasundaram S, Nagarajan N, et al. Utilization of 2D gahnite nanosheets as highly conductive, transparent and light trapping front contact for silicon solar cells. Appl Nanosci. 2019;9:1427. https: //doi.org/10.1007/s13204-018-00949-4

[28] Norrman K, Ghanbari-Siahkali A, Larsen N. 6 Studies of spin-coated polymer films. Annu Rep Sect $C$ Phys Chem. 2005;101:174. https://doi.org/10. $1039 / \mathrm{b} 408857 \mathrm{n}$

[29] Velu Kaliyannan G, Palanisamy SV, Rathanasamy R, Palanisamy M, Nagarajan N, Sivaraj S, et al. An Extended Approach on Power Conversion Efficiency Enhancement Through Deposition of ZnS-A12S3 Blends on Silicon Solar Cells. J Electron Mater. 2020;49:5937. https://doi.org/10.1007/s11664-020-08361-x

[30] Velu Kaliyannan G, Palanisamy SV, Rathanasamy R, Palanisamy M, Palaniappan SK, Chinnasamy M. Influence of ultrathin gahnite anti-reflection coating on the power conversion efficiency of polycrystalline silicon solar cell. J Mater Sci Mater Electron. 2020;31:2308. https://doi.org/10.1007/s10854-019-02763-2

[31] Deraz N, Alarifi A. Synthesis and characterization of pure and $\mathrm{Li} 2 \mathrm{O}$ doped $\mathrm{ZnFe} 2 \mathrm{O} 4$ nanoparticles via glycine assisted route. Polyhedron. 
2009;28(18):4122-30. https://doi.org/10.1016/ j.poly.2009.09.028

[32] Manohar A, Krishnamoorthi C, Naidu KC, Pavithra C. Dielectric, magnetic hyperthermia, and photocatalytic properties of $\mathrm{ZnFe} 2 \mathrm{O} 4$ nanoparticles synthesized by solvothermal reflux method. Appl Phys, A Mater Sci Process. 2019;125(7):477. https ://doi .org/10. 1007/s00339-019-2760-0

[33] Ajmal M, Maqsood A. AC conductivity, density related and magnetic properties of $\mathrm{Ni}_{1-x} \mathrm{Zn}_{x} \mathrm{Fe}_{2} \mathrm{O}_{4}$ ferrites with the variation of zinc concentration. Mater
Lett. 2008;62(14):2077-80. https://doi.org/10 . 1016/j.matlet.2007.11.019

[34] Mosleh M, Pryds N, Hendriksen PV. Thickness dependence of the conductivity of thin films (La,Sr)FeO3 deposited on $\mathrm{MgO}$ single crystal. Mater Sci Eng B. 2007;144(1-3):38-42. https://doi.org/10.1016/j.mseb.2007.07.089

Received 09-02-2021 Accepted 21-02-2021 